ISSN1027-5495. Functional Materials, 24, No.3 (2017), p. 427-433

doi:https://doi.org/10.15407/fm24.03.427

(C) 2017 - STC "Institute for Single Crystals"

\title{
The experimental research on axial compression performance of concrete-filled steel square tube strengthened by internal transverse stiffened bars
}

\author{
Nan $\mathrm{Li}^{12}$, Lai Wang ${ }^{2}$, Yajun $X i^{3}$ Hui Wang ${ }^{1}$, \\ Tong Guan ${ }^{1}$, Furui Dong ${ }^{1}$,Changfeng Sui ${ }^{2}$, Wenbin $\mathrm{Cui}^{1}$ \\ ${ }^{1}$ Department of Resources and Civil Engineering, Shandong University \\ of Science \& Technology, Taian, 271000,China \\ ${ }^{2}$ School of Civil Engineering and Architecture, Shandong University \\ of Science and Technology, Qingdao, 266590,China \\ ${ }^{3}$ Tai'an engineering construction standard cost office, Taian, \\ Shandong, 271000,China
}

Received December 15, 2016

\begin{abstract}
The application of Concrete-filled square steel tubular column in structural engineering is more and more widely. In order to improve the confinement of concrete core, the configuration of concrete-filled square steel tube strengthened by internal transverse stiffened bars is proposed. This paper employs a experimental research on concrete-filled square steel tube strengthened by internal transverse stiffened bars under axial compression and the influencing factors of bearing capacity such as diameter and spacing of steel bars is analyzed. The results shows that its axial load capacity is increased $2.3 \% \sim 13.1 \%$ than that of ordinary concrete-filled square steel tubular column, spacing changes to improve the bearing capacity of concrete filled square steel tubular column strengthened by transverse stiffened bars is more effective than the increase in stiffened bars diameter.

Keywords: Concrete-filled steel square tube, internal transverse stiffened bars, compressive load capacity, diameter; spacing
\end{abstract}

Применение квадратной стальной трубчатой колонны, заполненной бетоном, в структурной инженерии становится все актуальнее. Для улучшения удержания бетонного сердечника предлагается кондигурация бетонной квадратной стальной трубы, усиленной внутренними поперечными жесткими стержнями. В настоящей работе проведено экспериментальное исследование осевого сжатия квадратной стальной трубы, заполненной бетоном и упрочненной внутренними поперечными стержнями. Проанализированы фракторы, влияющие на ее прочность, такие как диаметр стальных стержней и расстояние между ними. Результаты показывают, что осевая прочность увеличена на $2,3 \% \sim 13,1 \%$, по сравнению с обычной заполненной бетоном квадратной стальной трубчатой колонной. Показано, что на упрочнение колонны более эффрективно влияет расстояние между упрочняющими стержнями, чем увеличение их диаметра. 
Експериментальне дослідження характеристик осьового стиснення залізобетонних сталевих квадратних труб, посилених внутрішніми поперечними жорсткими стрижнями Nan Li, Lai Wang, Yajun Xi, Hui Wang, Tong Guan, Furui Dong, Changfeng Sui, Wenbin Cui.

\begin{abstract}
Застосування квадратної сталевий трубчастої колони, заповненої бетоном, у структурній інженерії стає все більш актуальною. Для поліпшення утримання бетонного сердечника пропонуеться конфігурація бетонної квадратної сталевої труби, посиленою внутрішніми поперечними жорсткими стрижнями. У даній роботі проведено експериментальне дослідження осьового стиснення квадратної сталевої труби, заповненої бетоном і зміцненої внутрішніми поперечними стрижнями. Проаналізовано фрактори, що впливають на їі міцність, такі як діаметр сталевих стрижнів і відстань між ними. Результати показують, що осьова міцність збільшена на 2,3\% 13,1\%, в порівнянні зі звичайною заповненої бетоном квадратної сталевий трубчастої колоною. Показано, що на зміцнення колони більш ефективно впливає відстань між упрочняющими стрижнями, ніж збільшення їх діаметра.
\end{abstract}

\section{Introduction}

The concrete-filled steel square tubular concrete structure is composed of two different properties of steel and concrete. The outer steel pipe can effectively improve the internal concrete constraints, and concrete is better in the three-way pressure state, so that the concrete can play a better compression performance; at the same time, Concrete in the filling to save the template support costs owing to the existence of steel, improve the construction speed, improve the overall stability of the structure, it had more significant economic benefits $[1,2]$. Based on the above characteristics, the theoretical research and engineering application of concrete-filled steel tubular composite structure in civil engineering has become more and more extensive in recent years [3-6].

The axial and bending tests of 22 squareshaped CFST columns were carried out to study the axial and bending ultimate bearing capacity [7]. Knowles et al. [8] studied the ultimate bearing capacity of concrete-filled square steel tubes. The influence of slenderness and other factors on the axial compression performance is analyzed and compared with the section of the hollow steel pipe. It is shown that the confining effect of the steel pipe wall on the inner concrete obviously improves the ultimate bearing capacity of the concrete infill steel tube. Shkir K [10] studied the axial performance of 11 CFST columns with length of $3 \mathrm{~m} \sim 5 \mathrm{~m}$, and compared with the numerical results of finite element numerical simulation. It shows that the mechanical performance and economic effect of concrete-filled square steel tubular columns are better. Zed Hesham et al. [11] studied the stability and post-buckling properties of concrete-filled square steel tubular columns, and tested 24 concrete-filled steel tubular specimens and 6 empty steel pipe specimens. Hajjar et al. have simplified the constitutive relation of three-dimensional nonlinear finite element materials [12], and the slip between steel pipe and core concrete has been studied by defining non-linear elements.

A large number of studies have shown that in the concrete-filled square steel tubular columns, the confinement ability of the concrete core in the corner area is stronger than the middle of the square tube $[13,14]$. In this paper, a new type of CFST column section is proposed, the internal transverse stiffened bars is weld in the internal tube plate in order to strengthen the confinement of concrete core and local stability of square steel pipe wall, so as to enhance the ultimate bearing capacity and deformation capacity of concrete-filled square steel tubular columns.

\section{Experiment Program}

\subsection{Specimen design}

The dimension of the section is $200 \times 200 \mathrm{~mm}$, the length diameter ratio of $L / D$ is 3 , the height is $600 \mathrm{~mm}$, steel plate thickness of CFST specimens is $4 \mathrm{~mm}$. The spacing of internal transverse stiffened bars is $50 \mathrm{~mm}, 75 \mathrm{~mm}$ and $100 \mathrm{~mm}$ individually, the diameter of stiffened bars is $4 \mathrm{~mm}$ and $6 \mathrm{~mm}$, the length of stiffened bars is $180 \mathrm{~mm}$. The material of the steel plate is Q235B, the stiffened bar is HPB335. Typical section is shown in Fig. 1. The detailed dimensions of the test specimens are shown in Table 1.

\subsection{Materials properties}

All specimens were fabricated from steel sheeting with a measured thickness of $4 \mathrm{~mm}$. Based the test methods for mechanical properties of steel and concrete $[15,16]$, the yield strengths of the steel tubes are obtained as $231 \mathrm{MPa}$, which had been determined from tensile test on three coupons. The elastic modulus of every steel tube is taken as $203 \mathrm{GPa}$. Normal strength concrete with a water-cement ratio of 0.6 was used for the infill. The compressive strength of the concrete was determined from 
Nan Li et al. / The experimental research on axial compression ...

Table 1. List of detailed dimensions of specimen

\begin{tabular}{|c|c|c|c|c|c|c|c|}
\hline specimen & width, $\mathrm{mm}$ & height, $\mathrm{mm}$ & $\mathrm{t}, \mathrm{mm}$ & $\begin{array}{c}\text { diameter, } \\
\mathrm{mm}\end{array}$ & $\begin{array}{c}\text { length, } \\
\mathrm{mm}\end{array}$ & $\begin{array}{c}\text { spacing, } \\
\mathrm{mm}\end{array}$ & $\begin{array}{c}\text { ultimated } \\
\text { load, } \mathrm{kN}\end{array}$ \\
\hline A0 & 200 & 600 & 4 & None & None & None & 1570 \\
\hline A1 & 200 & 600 & 4 & 4 & 180 & 100 & 1607 \\
\hline A2 & 200 & 600 & 4 & 4 & 180 & 75 & 1670 \\
\hline A3 & 200 & 600 & 4 & 4 & 180 & 50 & 1720 \\
\hline A4 & 200 & 600 & 4 & 6 & 180 & 100 & 1640 \\
\hline
\end{tabular}

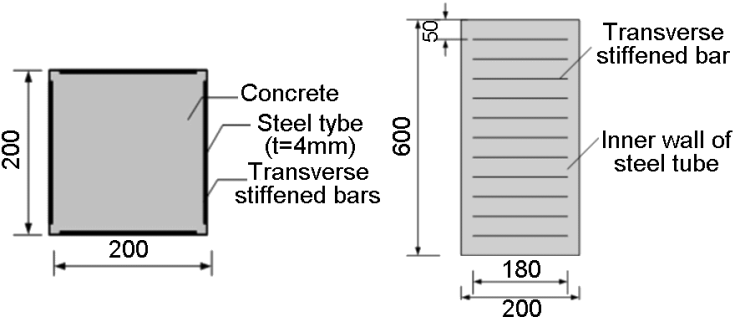

Fig. (1). Typical section

three $150 \mathrm{~mm}$ cubes taken from each batch of concrete. The average concrete cubic strength at 28 days of curing age are $31.6 \mathrm{MPa}$ for specimens that were prepared for the compression test.

\subsection{Test Layout}

The test is completed on the YAW-3000A electro-hydraulic servo pressure testing machine. Before the axial compression test, the concrete filled square steel tubular short column specimens placed in a press car, adjust the position to ensure the location of the specimen center, and pushed it to the loading position, then adjust the height of top pressure plate, make the distance between the top surface of specimens and pressure plate as close as possible. Square steel tube concrete short column pre load is $200 \mathrm{kN}$, check the measurement instrument and the loading work is normal. Loading procedure is the way of hierarchical axial loading. In the elastic stage, the load value of each stage is about $10 \%$ of the ultimate load value, the specimen is about $150 \mathrm{kN}$, and the concretefilled steel tubular short column reaches the yield stage and the load classification is further reduced. When the load increased to $85 \%$ of the calculated ultimate load, make the load continuously slowly until the specimen reaches the ultimate bearing capacity. The loading interval time is controlled in 2 minutes.

\subsection{Measuring arrangement}

The main measurement contents of the axial compression test include the vertical and horizontal strain of the column, the column longitudinal displacement and the pressure value. The longitudinal strain is composed of steel pipe

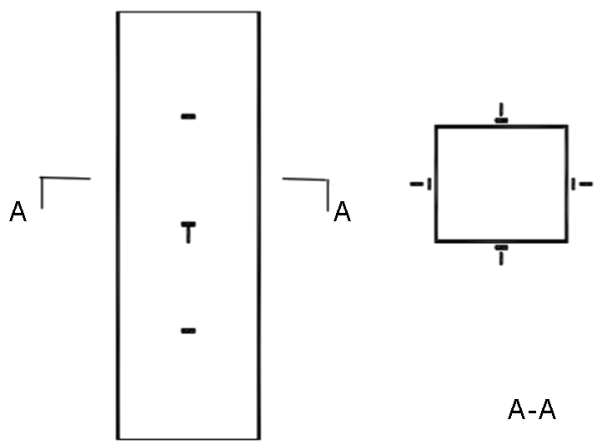

Fig. 2. Placement of strain gauge

column attached to the outer surface of each surface, located in the height of the specimen of $1 / 2$, the transverse strain measured by strain gauge, pasted on the outer surface of steel pipe column, located in the cross section width of $1 / 4,1 / 2$ and $3 / 4$, as shown in Fig. 2. The strain data were collected by DH3816N static strain collection instrument. In this test, the ultimate load and displacement is measured by the pressure sensor synchronously, and the load displacement curve is drawn, which is convenient to control the whole loading process.

\section{Results and Discussion}

\subsection{Failure mode}

In the elastic loading stage, specimen A0 has no changes in appearance. When the load reaches $1400 \mathrm{kN}$, the steel tube in the upper surface slightly bulged; when reaching the ultimate load of $1610 \mathrm{kN}$, the upper surface of square steel tube deformation increasing with the pressure rising obviously, while load decreased slowly, finally the load is stability at $1300 \mathrm{kN}$.

In the test of the other 6 specimen(A1 A6), the overall trend of load-displacement curve is similar, which can be divided into four stages in the loading process, when the load is less than 0.85 times of ultimate load of specimen, with the increase of load, vertical displacement increases; when the load limit load is 0.85 times greater than ultimate load, the specimen enter the elastic-plastic stage, the relationship be- 
tween load and displacement is non-linear. The axial load increases gradually with the increase of vertical displacement, but the increase rate is less than the elastic stage; when the load is greater than the ultimate load, the specimen enter the failure stage, the surface of the specimen is generally outward. The bearing capacity of concrete filled square steel tubular column decreases gradually, and the displacement increases and then tends to be stable. In the case of different diameter and spacing of reinforced concrete, the ultimate load of the bearing capacity is different, the bigger the diameter of transverse stiffened bar is and the smaller the spacing is, the greater the ultimate bearing capacity is.

\subsection{Comparison of load and displace- ment curves}

The load displacement curves of concrete filled square steel tubular column and reinforced concrete filled square steel tubular column are shown in Fig. 3 and Fig.4.

As seen from Fig. 3 and Fig. 4, load-displacement curve of concrete filled square steel tubular column and concrete filled square steel tubular columns strengthened by transverse stiffened bars can be divided into four stages: elastic stage, elastic-plastic stage, failure stage and steady decline stage. the bearing capacity of concrete filled square steel tubular columns strengthened by transverse stiffened bars is higher than that of concrete filled steel tubular columns. It can be seen from the above diagram that the axial compression bearing capacity increases with the decrease of the transverse reinforcement spacing in the case of constant transverse reinforcement diameter. in addition, peak displacement of $\mathrm{A} 1 \sim \mathrm{A} 6$ is bigger than $\mathrm{A} 0$ due to type of transverse stiffened bars, while the final displacement can reach 10 15 mm individually.

\subsection{Ultimate bearing capacity of con-} crete filled square steel tubular column strengthened by transverse stiffened bars

(1) The comparison of the effect of the horizontal reinforcing steel bar on the bearing capacity.

As seen from the Table 1 and Fig. 5, The bearing capacity of concrete filled square steel tubular column with internal transverse stiffened bars is bigger than that of ordinary concrete filled square tubular column, The maximum increasing rate is $13.1 \%$, the minimum increasing rate reached $2.3 \%$. This is mainly due to the weak restrictions on core concrete in square steel tube. After adding the transverse stiffened bars, the confinement between the square steel tube and concrete is strengthened, the concrete core is compressed from three di-

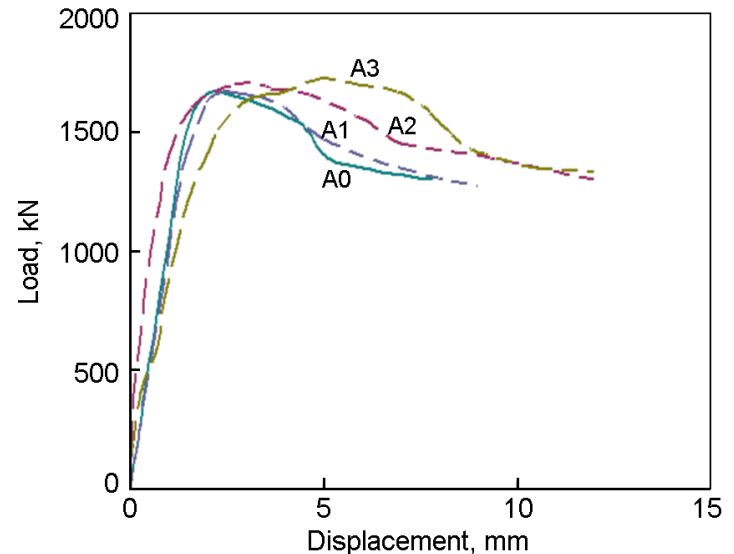

Fig. 3. Load-Displacement curves of A0 A1 A2 and $\mathrm{A} 3$

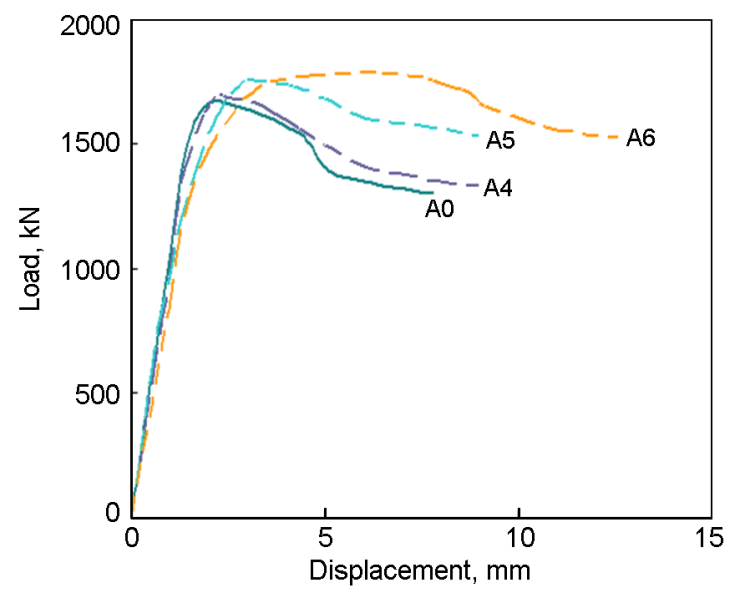

Fig. 4. Load-Displacement curves of A0 A4 A5 and $\mathrm{A} 6$

rections, thereby improving the core concrete compressive strength, improve the bearing capacity of the concrete confinement reinforced with horizontal tube.

(2) The effect of the diameter change of transverse stiffened bar on the bearing capacity.

Of the A1 A6 specimens, when the spacing of the transverse stiffened bar is $100 \mathrm{~mm}$, with a diameter of $4 \mathrm{~mm}$ stiffened bars, ultimate bearing capacity of square steel tubular column is $1607 \mathrm{kN}$, with a diameter of $6 \mathrm{~mm}$ stiffened bars, it is $1640 \mathrm{kN}$, the change of the diameter bring $33 \mathrm{kN}$ increase in ultimate bearing capacity, the ultimate bearing capacity increased only $1.5 \%$; When the spacing of the transverse stiffened bar is $75 \mathrm{~mm}$, with a diameter of $4 \mathrm{~mm}$ stiffened bars, ultimate bearing capacity of square steel tube column is $1670 \mathrm{kN}$, with a diameter of $6 \mathrm{~mm}$ stiffened bars, ultimate bearing capacity of square steel tube column is $1710 \mathrm{kN}$, the diameter of the changes that improve the bearing capacity of $40 \mathrm{kN}$ compared with the ultimate bearing capacity only increased by $2.2 \%$; when the spacing of 


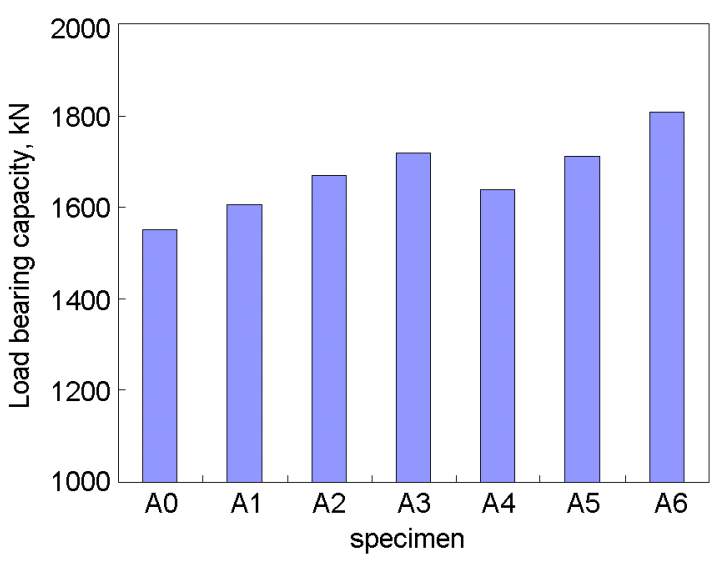

Fig. 5. Comparison of ultimate bearing capacity

the stiffened bar is $50 \mathrm{~mm}$, with a diameter of $4 \mathrm{~mm}$ stiffened bars, ultimate bearing capacity of square steel tubular column is $1720 \mathrm{kN}$, with a diameter of $6 \mathrm{~mm}$ stiffened bars, ultimate bearing capacity of square steel tubular column is $1806 \mathrm{kN}$, the diameter of the changes that improve the bearing capacity of $86 \mathrm{kN}$ compared with the ultimate bearing capacity increased only $3.8 \%$.

The above analysis shows that in concrete filled square steel tubular column strengthened by transverse stiffened bars, the bar diameter changes can improve the bearing capacity of concrete with horizontal reinforced stiffened square steel tube is not obvious.

(3) The effect of the spacing change of transverse stiffened bar on the bearing capacity

Of the A1 A6 specimens, when the transverse stiffened bar diameter is $4 \mathrm{~mm}$, spacing is $100 \mathrm{~mm}$, ultimate bearing capacity is $1607 \mathrm{kN}$, while spacing is $75 \mathrm{~mm}$, ultimate bearing capacity is $1670 \mathrm{kN}$, spacing is $75 \mathrm{~mm}$, ultimate bearing capacity is $1720 \mathrm{kN}$, the change of distance between above two bring $50 \mathrm{kN}$ and $63 \mathrm{kN}$ increase in capacity individually, increased by $4.5 \%$ and $6.5 \%$ compared to the ultimate bearing capacity of the above two; when the diameter of transverse stiffened bar is $6 \mathrm{~mm}$, spacing is $100 \mathrm{~mm}$, the ultimate bearing capacity of steel column is $1670 \mathrm{kN}$, spacing is $75 \mathrm{~mm}$, ultimate bearing capacity is $1710 \mathrm{kN}$, spacing is $50 \mathrm{~mm}$, ultimate bearing capacity is $1806 \mathrm{kN}$, the change of distance between above two are $96 \mathrm{kN}$ and $40 \mathrm{kN}$ increase in capacity individually, increased by $4 \%$ and $5 \%$ compared to the ultimate bearing capacity of the above two. The above analysis is shown that in concrete filled square steel tubular column strengthened by transverse stiffened bars, spacing change is conducive to improve the bearing capacity of column, which is to enhance bearing capacity, reduce spacing of the transverse stiffened bars is more effective than increasing the steel rib diameter.
The above analysis shows that concrete filled square steel tubular column strengthened by transverse stiffened bars, spacing changes to improve the bearing capacity of concrete filled square steel tubular column strengthened by transverse stiffened bars is more effective than the increase in stiffened bars diameter. When the diameter of stiffened bar is smaller, especially in less than the thickness of the steel plate in steel tube concrete, this improvement of the bearing capacity is not obvious.

\subsection{Comparative analysis of transverse} strain

Transverse strain of three section on all specimens are shown in Fig. 6 - Fig. 8 .

In short, due to the constraint effect of lateral reinforced, transverse strain is less than the transverse strain of concrete filled square steel tube column reinforced concrete with horizontal square steel tubular column; at the same time decreases with distance of horizontal reinforced, concrete filled square steel tubular column corresponding to transverse strain lower position, transverse stiffening bar diameter affected by the increase of transverse strain is not obvious; with horizontal reinforced concrete filled square steel tubular column is confined to the core of the transverse stiffener reinforced concrete in steel tube, the constraint effect of built-in transverse stiffener reinforced ribs of concrete-filled square steel tubular column strengthened, from the change of each section of the column lateral strain is uniform, the stress in the process of variation of transverse strain in each cross section were small.

\subsection{Ductility index of each specimen}

Compared with concrete structure, concrete filled steel tubular structure shows better ductility. In order to reflect the ductility of concrete filled steel tube, the use of the existing definitions of ductility index, that is to say, the formula is

$$
D I=\frac{\mu_{2}}{\mu_{1}}
$$

where, DI - Ductility Index; $\mu_{1}$ - the displacement When reaching the ultimate load; $\mu_{2}$ - the displacement when the force reduced the $85 \%$ limit load.

As seen from Table 2, the ductility of reinforced concrete with horizontal rectangular steel tube column is greater than the ordinary concrete filled square steel tube column; the specimens in the transverse stiffener bar diameter were $4 \mathrm{~mm}$ and $6 \mathrm{~mm}$, bar spacing is reduced from $100 \mathrm{~mm}$ to $50 \mathrm{~mm}$, the ductility of concrete with transverse stiffening bars increased by $8.6 \%$ and $9 \%$. Comparison figure in ductility 
Table 2. $D I$ of specimens

\begin{tabular}{|c|c|c|c|}
\hline specimen & $\mu_{1}$ & $\mu_{1}$ & $D I$ \\
\hline A0 & 2.8 & 4.5 & 1.57 \\
\hline A1 & 2.9 & 5.1 & 1.74 \\
\hline A2 & 3.0 & 5.4 & 1.81 \\
\hline A3 & 3.3 & 6.2 & 1.89 \\
\hline A4 & 3.1 & 5.6 & 1.77 \\
\hline A5 & 3.5 & 6.4 & 1.84 \\
\hline A6 & 3.9 & 7.4 & 1.93 \\
\hline
\end{tabular}

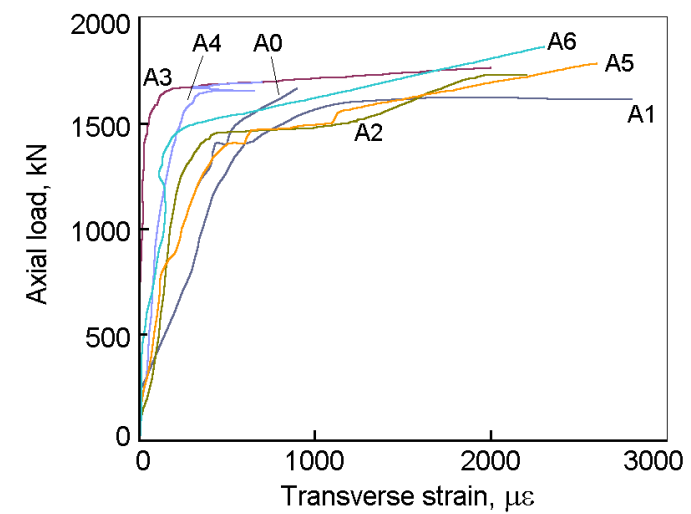

Fig. 6. Transverse strain of upper section on specimens

of specimens can be seen from Fig. 9. Increase of bar diameter can improve the ductility of concrete filled square steel tube, but the ductility index increase is not obvious. Therefore, in order to increase the ductility of concrete-filled square steel tubular column with inner transverse stiffening ribs, the spacing of transverse stiffeners should be reduced.

\section{Conclusion}

This paper is concerned with the experiment of concrete-filled square steel stub columns strengthened by internal transverse stiffened bars under axial compression. The following conclusions can be drawn based on the results of this study:

(1) Through the experiments of concretefilled square steel tubular column and concretefilled square steel tubular column strengthened by internal transverse stiffened bars under axial compression, it is shown that the load-displacement performance of this type of concrete filled steel tubular column is similar with the ordinary concrete filled square steel tubular column, but bearing capacity of this new type of column has been improved in certain extent, the maximum increase $13.1 \%$.

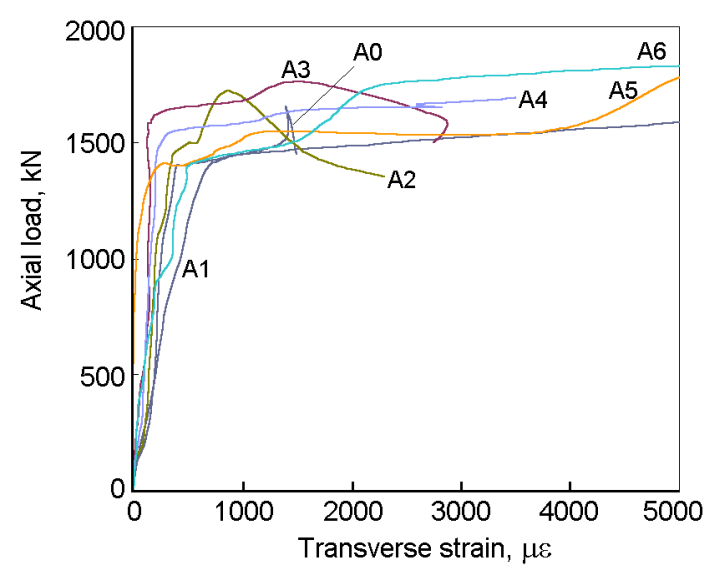

Fig. 7. Transverse strain of middle section on specimens

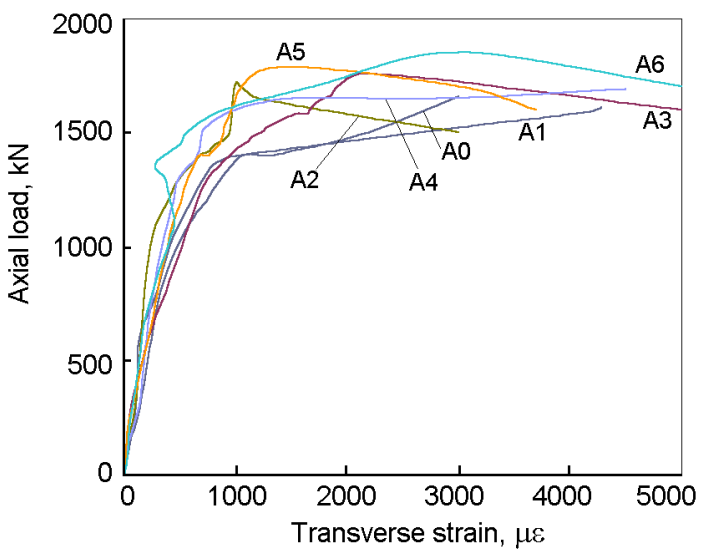

Fig. 8. Transverse strain of bottom section on specimens

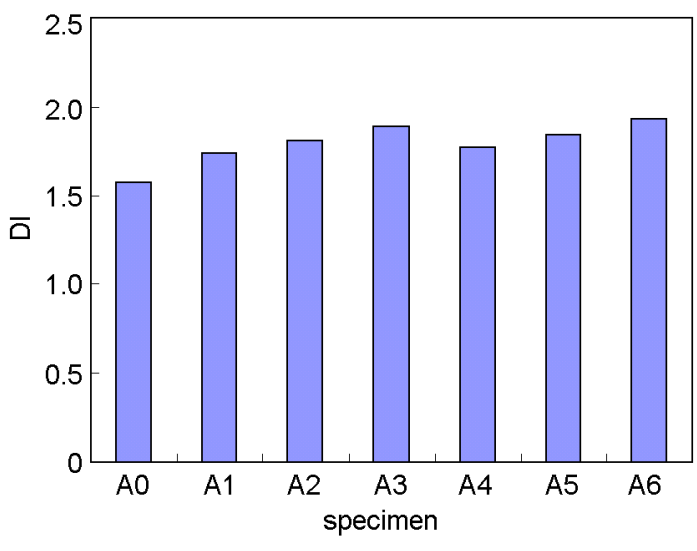

Fig. 9. Comparison figure in ductility of specimens

(2) The transverse strain of the reinforced concrete filled square steel tubular column is smaller than that of the concrete filled square steel tube column due to the restriction of the inner transverse reinforcement on the core concrete; 
(3) Compared with the increase of transverse reinforcement diameter, reducing the transverse reinforcement spacing can improve the ultimate bearing capacity and ductility more effectively.

\section{Acknowledge}

The authors gratefully acknowledge the fi $\neg$ nancial support from the Technology Project of Shandong Province Construction Department of Urban and Rural Housing of China under Grant No. 2016KY028, Scientific Research Innovation Team Support Plan of Department of Resources and Civil Engineering of Shandong University of Science and Technology and 2016 national university student innovation and entrepreneurship training program project. (No. 201613624002)

\section{References}

1. Zhong Shan Tong. Steel Pipe Concrete (3rd Edition) $[\mathrm{M}]$. Beijing: Tsinghua University Press, 2002

2. Han Linhai. Concrete-filled steel tube structure - theory and practice, Beijing: Science Press, 2004

3. Cai Shaohuai. Modern concrete-filled steel tube (first edition), People's Communications Press, 2003

4. Han Linhai. Steel Pipe Concrete Theory and Practice (2nd Edition), Beijing: Science Press, 2007

5. Han Linhai, Yang Youfu. Modern concrete-filled steel tube technology, China Construction Industry Press, 2004
6. Zhong Shan Tong. High-rise concrete-filled steel tube structure, Harbin: Heilongjiang Science and Technology Press, 1997

7. Furlong, R. W., J.Struct. Div., 93(5), 113, 1967

8. R. B. Knowles, R. Park, J. Struct. Div. ASCE, 95(2), 2565, 1969

9. K.Cederwall, B. Engstrom, M. Grauers, Second International Symposium on Utilization of HighStrength Concrete, Hester, W. T, Berkeley, California. May, 1990: 195-214.

10. H. Shakir-Khalil, J. Zeghiche, The Struct.Eng., 67(9), 346, 1989.

11. Matsui. C, Tsuda. K and El Din, H. Z. Stability design of slender concrete filled steel square tubular columns. Proceedings of the 4th East Asia-Pacific Conference on Structural Engineering and Construction, 1993,(1),317-322

12. Jerome F. Hajja, Aleksandr Molodan, Eng. Struct., 20(4), 398, 1998

13. K. Tsuda, C. Matsui, E. Mino, Strength and behavior of slender concrete filled steel tubular columns stability problems in designing, Construction and Rehabilitation of Metal Structures Proceedings of the Fifth International Colloquium on Structural Stability, 1996: 489-500.

14. H. Shakir-Khalil, A. Al-Rawdan, Experimental behavior and numerical modeling of concrete-filled rectangular hollow section tubular columns. Composite Construction in Steel and Concrete III, 1997, 222-235.

15. National Standard of the People 's Republic of China, GB / T228-2002, Test Method for Room Temperature Tensile Testing of Metals, Beijing: China Standard Press, 2002

16. National Standard of the People's Republic of China, GB / T50081-2002, Standard Test Method for Mechanical Properties of Ordinary Concrete, Beijing: China Construction Industry Press, 2002 